Tarrow, Sidney. 1994. Power in Movement: Social Movements, Collective Action and Politics. Cambridge: Cambridge University Press.

Tarrow, Sidney. 1989. "Struggle, Politics and Reform: Collective Action, Social Movements and Cycles of Protest." Cornell University, Westem Societies Paper no. 21.

Tilly, Charles. 1978. From Mobilization to Revolution. Reading, MA.:Addison-Wesley Publishing Company.

Turner, Ralph H. and Lewis M. Killian. 1987 [1957]. Collective Bebavior. Englewood Cliffs: Prentice-Hall, Inc.

United States General Accounting Office. 1995. "GAO Interim Report GAO/NSIAD-95-66R, 'Chemical Stockpile Disposal Program Review'." Washington, D.C.: General Accounting Office.

Vig, Norman J. 1990. "Presidential Leadership: From the Reagan to the Bush Administration." Pp. 33-58 in Environmental Policy in the $1990^{\prime}$, edited by Norman J. Vig and Michael E. Kraft. Washington, D.C.: Congressional Quarterly Inc.

Walsh, Edward, Rex Warland and D. Clayton Smith. 1993 "Backyards, NIMBYs and Incinerator Sitings: Implications for Social Movement Theory." Social Problems 40:25-38.

Walton, John. 1992. Western Times and Water Wars: State, Culture and Rebellion in California. Berkeley: University of Califomia Press.

Weller, Jack. 1994 "Describing and Analyzing Social Actions of Social Movements." Unpublished.

Wenner, Lettie M. 1990. "Environmental Policy in the Courts" Pp. 189210 in Environmental Policy in the 1990's, edited by Norman J.Vig and Michael E. Kraft. Washington, D.C.: Congressional Quarterly Inc.

Yang, Yu-Chu. 1995. "Chemical Reactions for Neutralising Chemical Warfare Agents". Chemistry or Industry May:334-337.

\section{THE CONTINUITY OF VIOLENCE IN THE STAGES OF THE SHI-SHI MOVEMENT OF NINETEENTH-CENTURY JAPAN}

\author{
YUICHI TAMURA \\ University of Kansas
}

MARS/Social Thought \& Research, 1997, Vol. 20, No. 1-2

\begin{abstract}
Some scholars place violence as prominent in an early stage of a social movement, whereas others argue that violence is characteristic of a later stage. This paper addresses the question of whether there is a specific movement stage that is particularly characterized by violence through an analysis of the shi-shi movement (1858-1864). The shi-shi movement belped create the revolutionary situation which culminated in Japan's Meiji Restoration (1868). Violence was prominent and consequential in the shishi movement and was found throughout the career of the movement. This study of a single case is by no means sufficient to claim primacy over existing models of the place of violence in social movements. The shi-shi movement, however, significantly varies from theoretical models that link violent actions to a specific movement stage.
\end{abstract}

Social movements have careers. They go through stages as they emerge, develop, and decline. Scholars have characterized successive stages of social movements as indicated by the forms of action found in each stage. Violence is one of the indicators used to identify the action said to typify particular social-movement stages. In this paper, I examine the pattern of violence in stages of the shi-shi movement in 19th century Japan in comparison with two ways in which scholars have linked violence to phases of social movements.

Violence is one type of action often associated with social movements. Research on violent actions in social movements mainly addresses two issues. One line of exploration focuses on the causes of violent actions. For example, violence has been explained as an effect of relative deprivation (Gurr 1970; Davies 1962), resource allocations (McCarthy and Zald 1977; Oberschall 1973, 1993) or political conditions (Snyder 1979; Snyder and Tilly 1972; Tilly 1978; Tilly et. al. 1975). The other issue concerns the phase of a social movement in which violent 
actions take place (Blumer 1939; Hopper 1950; Tumer and Killian 1987; Tarrow 1993, 1994; Feagin and Hahn 1973; McAdam 1983; Miller 1983; McAdam and Moore 1989)

This paper discusses little about the causes of violent actions in social movements and focuses on the second issue of whether there is a specific movement stage which is particularly characterized by violent actions. This issue is examined for the pattem of violent actions in the shi-shi movement of 19 th-century Japan. The shi-shi movement is characterized by the persistence of violent actions that had significant effects on ongoing social and political struggles and the emergence of the revolutionary situation. ${ }^{1}$ The main tasks of this paper are 1) to evaluate characterizations that relate violence to a particular social-movement stage and, more specifically, 2) to assess empirically the contrasting arguments about whether violence is a characteristic of an early or a later phase of the shi-shi movement. The main questions to be explored in this paper are: How do the arguments by the scholars relating violence with stages apply to the shi-shi movement, and what does the shi-shi movement suggest about the usefulness of identifying movement stages in terms of the presence or absence of violence?

\section{Violence as a Characteristic of Social Movement Stages}

There are two contrasting arguments on the characterization of social movement stages in terms of violent actions. Some writing from "collective behavior" perspectives view violent actions as prevalent in an early stage of a movement (Blumer 1939; Hopper 1950; Tumer and Killian 1987). Others emphasizing the "political process"2 variant of the "resource mobilization" perspective argue that violent actions take place in a later period of a social movement (Tarrow 1993, 1994; McAdam 1983, 1986; Miller 1983; Evans 1983; Della Porta 1995). This paper will compare patterns of violence in the shi-shi movement in 19th-century Japan with these contrasting characterizations of social-movement stages in terms of violence.

Blumer's perspective on social movements raises important issues for empirical analysis. Blumer conceives of a social movement as "episodic in its career, with very scattered manifestations of activity..." (1939, p.257). He claims, "It is necessary to view social movements from

1 Thus, the shi-shi movement is historically significant, as well as exhibiting an interesting pattern of violent actions. The revolutionary situation it helped to create set the stage for the Meiji Restoration (1868), the social revolution which began Japan's rapid transition from feudalism to a modern system.

2 "Political process" writers emphasize political opportunity structures as well as movement organizations and resources in understanding social movements. 170 this temporal and developmental perspective..." (Blumer 1939, p.259). $\mathrm{He}$ analyzes a career of a social movement as the development of successive stages. "In their early stages, social movements are likely to be merely an aggregation of individual lines of action based on individual decisions ..." (Blumer 1939, p.258). A movement's "organization and its culture are developed in the course of its career..." (1939, p.259). Successive stages have "increasing organization" (Blumer 1939, p.259). Sporadic, uncoordinated actions characterize the early stage and organized, coordinated actions, a later stage.

Similarly, in their life-cycle models of social movements, Tumer and Killian (1987) and Hopper (1950) emphasize a developmental nature of social movements which is characterized by the increasing organization of movement actions. In these models, social movement action proceeds from a dispersed stage to an organized stage. Violence is one type of action specifically thought to occur in the early stage of a social movement. ${ }^{3}$ The main issues of this paper in relation to the argument of Blumer (1939) are, therefore: Does sporadic violence characterize an early stage of the shi-shi movement? Does violence decrease or disappear as a movement progresses, to be replaced by more organized and coordinated actions?

Others argue that violent actions occur later in the career of a social movement. Tarrow $(1993,1994)$ and Tilly $(1993)$ examine repertoires of contention in the cycles of protest and argue that an early stage of a movement is characterized by the prevalence of "conventional" tactics (Tarrow 1993, p.289) that minimize the costs of protest. These scholars regard violent actions as prevalent in the later phase when social movements lose their mass support (Tarrow 1994, p.103; McAdam 1983, p.311; Feagin and Hahn 1973, p.43) and face countermovements (Della Porta 1995, p.162). The later-stage characterization is also supported by McAdam's "model of recruitment to high risk/high cost activism" which argues that movement actions start with the "low cost/low risk activity" and later move on to actions with higher risk (1986, p.68-71). This paper will examine empirically their arguments that 1) violence is a characteristic of a later movement stage, because 2) violence occurs

"Some terms used to characterize actions in the early stage of a social movement such as "sporadic", "random and erratic behavior", "agitation", "dispersed", "impulsive behavior" (Blumer 1939, pp.259, 260), "unorganized and unformulated" (Hopper 1950, p.271) can be interpreted in different ways. Violence is by no means the only type of sporadic action, but clearly is one of them (cf. Blumer 1978, p.17). Violent actions are not necessarily sporadic and unorganized. The researchers on collective violence (Tilly 1978; Snyder 1979; Snyder and Tilly 1972; Rule 1988) show oromized and coordinated aspects of violence. This paper no means actions. Rather, the initial question is whether violence constitutes an empirically valid indicator of the stages of the sbi-shi movement. 
when social movements lose resources and opportunities for conventional political actions ${ }^{4}$.

In the following section, I will trace violent actions in an early phase of the shi-shi movement. Then I will describe the concurrence of violent actions with organized, sustained political campaigns in a later phase. This empirical analysis of the shi-shi movement will show that sporadic violent actions were continuous throughout the movement's career Moreover, close examination of the shi-shi movement indicates an increase in sporadic violence when political opportunities for the shi-shi expanded, rather than when other channels of social movement actions closed.

\section{The Shi-Shi Movement}

The abolition of the shogunate political system in 1867 and the sweeping reforms that followed, constituted the most dramatic political transformation in Japanese history. Called the Meiji Restoration, this social revolution was achieved through political actions taken by a variety of actors, including the bakufu (the national shogun govemment), nobles of the emperor's court, feudal domain bureaucrats, samurai, and foreign states.

One of the factors that contributed to the failure of the shogun governmental system was a series of actions attributed to shi-shi (literally, men of high purpose), young samurai who began with little political power. The shi-shi actions taken between 1858 and 1864, constitute the shi-shi movement. These actions included terrorism against foreigners and Japanese officials and campaigns for political influence in Kyoto, the capitol, as well as in several important feudal domains. 5 This movement significantly contributed to the creation of a revolutionary situation which soon culminated in revolutionary outcomes ensuing from the Meiji Restoration in 1868.

${ }^{4} \mathrm{My}$ discussion on this point does not imply any causal conclusions on the relationships between violent actions and loss of resources and opportunities, although their relationships are examined in empirical analyses of Della Porta 1995; Miller 1983; Tarrow 1993, 1994) question of the quion and opportunities. In other words, this paper asks empirically whether violence in the shi-shi movement coincided with the changing political conditions in which the movement lost support from outside groups, and thus political opportunity structure had contracted.

5The feudal domains in the Tokengavwa shogunate system are of three types: Shimpan, related by blood to the Tokugawa family; fudai, supporters of Tokengawa when they consolidated power in the battle of Sekigabam in 1600; and tozama, opponents in the battle of Sekigabam. Tozama domains were headed by subordinated, but rival families to the Tokugana shogunate. Choshu, Satsuma, and Tosa were tozama domains active in significant ways in the shogunate. Choshu, Satsuma, and Tosa were
political campaigns of the shi-shi movement

\section{Early Shi-Shi Violence}

The shi-shi movement began, as Blumer (1939, p.259) suggests movements do, as an aggregation of sporadic actions without central coordination and control. Most of the significant actions taken in the initial stage of the shi-shi movement were agitating acts of terrorism. On June 2,1859 , in accordance with a commercial treaty concluded in the previous year, the representatives from five countries (United States, Great Britain, France, Russia, and Holland) began residing in Japan for the purpose of international trade 6 .

The first incident of terrorism occurred against foreigners on July 20,1859 , when an officer and a seaman, both from Russia, were attacked and cut to pieces. Russia planned retaliation, but settled for the bakufi's official apology and its promise to arrest the assassins (Konishi 1966, p.243). In October, a Chinese man employed by the French consulate was attacked and killed (Konishi 1966, p.243). On January 7, 1860, a translator for the British legation was killed. The bakufu (the shogun government) paid compensation to Great Britain. Assassinations of two Dutch merchant captains in February and of an Italian working for the French consulate in June followed (Konishi 1966, p.244).

On December 5, 1860, Hendrix Heusken, a secretary and translator for the U.S. representative was assassinated by shi-shi from Satsuma domain (Hesselink 1994, pp.331-337). The bakufu paid $\$ 10,000$ to Heusken's family (Konishi 1966, pp.244-245). Then, in May, 1861, fourteen shi-shi from Mito domain attacked the British legation in Edo. They aimed to kill all foreigners at the legation according to their subsequent confession, but they were arrested first (Konishi 1966 , pp.245-246).

Except for the case of the attack on the British legation, no terrorists responsible for these incidents were arrested. Because of the anonymity of the assassins in most cases, it cannot definitely be asserted that all of these actions were actually taken by those who identified themselves as shi-shi. These events, however, were seen as types of action the shi-shi would take, because the anti-foreign character of these incidents

6 The bakufu (the shogun governmeit) had enforced the seclusion policy since the early 17th century until a treaty with Commodore Matthew C. Perry of America in 1854. The controversy surrounding the opening of the country and the subsequent political process, including the "Ansei purge" against those who continued to resist the presence of foreigners, constituted the setting for the sbi-shi movement. Detailed descriptions of this political process are provided by Beasley (1972), Craig (1961), Huber (1981), Jansen (1961), Konishi (1966), and Pyle (1978). 
corresponded with the shi-shi's anti-foreign sentiments (Morikawa 1967, p.38; Konishi 1966, p.242; Shibahara 1975, pp.130-131).

In an analysis of violence, such as terrorism, the question of whether it was under the control of any particular groups or organizations must be considered. Edwards argues that disruptive actions are "always raised and organized for the purpose by a small group of leaders ... and carefully planned out beforehand" (Edwards 1970[1927], p.101). Some terrorist episodes were carried out by groups of shi-shi, and thus imply some coordination. Unlike Edwards' assertion, however, there is no indication that anti-foreign terrorism during these years was purposefully planned and coordinated by any particular group. Rather, as Blumer (1939) suggests, these anti-foreign actions in the early stage of the shi-shi movement appear to be an aggregation of sporadic, separately-mounted actions.

Violence against foreigners occurred frequently between 1859 and 1861. During this early stage, however, "the most dramatic act of terrorism was the assassination of [bakufu leader] Ii Naosuke, [a] symbol of the arbitrary attitude of the bakufu and of its concession to the foreigners" (Duus 1976, p.67). On March 3, 1860, eighteen shi-shi (one from Satsuma domain and the others from Mito domain) attacked Ii's procession at the Sakurada gate of Edo castle and killed him. Five of the shi-shi lost their lives in the fighting. The others surrendered themselves to the bakufu authority and submitted a prospectus explaining their action (Konishi 1966, pp.151-156).

The significance of the assassination of Ii Naosuke for the political process in Japan was enormous (Sakata and Hall 1956; Harootunian 1970; Duus 1976). First, it had an intimidating effect on the officials of the bakufu and resulted in moderation of the bakufu policy (Sakata and Hall 1956, p.43; Huber 1981, p.100). After Ii's assassination, the bakufu never again asserted firm control in the state decision-making process. Second, this event gave the shi-shi an example of a successful direct action that influenced national politics (Beasley 1972, 1990). As Tilly argues, prior success and failures may produce a "change in the repertoire of collective actions" (1978, p.158). Before Ii's assassination, no direct action against a Bakufu official with such superior status was recorded in the Tokugawa period (Hirao 1930; Morikawa 1967), whereas the shi-shi engaged in many direct actions against officials after li's assassination. As Harootunian notes, the assassination of Ii marked the beginning of "a new kind of play with the imperial capitol of Kyoto as its stage" (1970, p.247)
Violence in the Shi-Shi Movement

Blumer (1939) and some other scholars (for example, Hopper 1950; Tumer and Killian 1987) characterize actions at the beginnings of social movements as not taken by an organization. During the early years of the movement, shi-shi took a number of very similar terrorist actions. The assassination of Ii and the violent attack of the British legation, at least, were carried out by groups of shi-shi, implying coordination and planning. There is, however, no indication of unified coordination or control of the series of actions or the movement in its early stage. As Blumer (1939) leads us to expect, the early stage of the shi-shi movement was an aggregation of sporadic actions.

\section{The Later Shi-Shi Movement}

After Ii's assassination, shi-shi attacks were less frequent for about two years. Only two attacks of foreigners are recorded. Then, an attempt in early 1862 to assassinate Ando Nobumasa, one of the most powerful bakufu officials after Ii, marked the beginning of the shi-sbi movement's most active period, which lasted until 1864. This later stage followed Blumer's generalization that "as a social movement develops, its behavior which was originally dispersed tends to become organized, solidified and persistent" (1939, p.259). Shi-shi actions included organized, centrally-coordinated political campaigns in Kyoto and several feudal domains. Also, however, this phase of the shi-shi movement mixed sporadic episodes of political terrorism with sustained political campaigns. Shi-shi terrorism against Japanese political opponents continued.

Concurrence of political campaigns and sporadic violence raises the questions about characterizations which associate violence with movement stages. In the shi-shi movement, sporadic violent actions continued and increased in frequency during the later period of the movement. The process of organized campaigns during the shi-shi movement follows the arguments of Blumer (1939), Hopper (1950) and Turner and Killian (1987) that a movement proceeds from dispersed to organized and coordinated action. In the shi-shi movement, however, an increasing organization of movement actions did not entail a disappearance or even a decrease of sporadic actions.

Secondly, in the shi-shi movement, violent actions increased when the shi-shi gained the support of polity groups such as feudal domains and the imperial court, then stopped when it lost that support. This is the reverse of the argument by Tarrow (1994), McAdam (1983) and Miller (1983) that violence occurs in the later period of a movement when activists lose broad support. In the following section, I will describe the 
concurrence of organized shi-shi political campaigns with sporadic, but consequential, violent actions.

\section{Political Campaigns ${ }^{7}$}

During the later stage of the shi-shi movement (1862-1864), those who identified themselves as shi-shi conducted influential political campaigns in Kyoto ${ }^{8}$ and in some feudal domains, such as Choshu and Satsuma. After li's assassination, Ando Nobumasa attempted to placate opposition by adopting what was called the kobugattai policy, which signified a political coalition between the imperial court and the bakufu through a marriage between the shogun and a sister of the emperor. The term "kobugattan" embodied the ideal of cooperation of court nobility and samurai, presumably for the purposes of the whole society's well-being (Totman 1975, p.393). Initially, this policy was supported by a number of lords of great domains', including the tozama domains of Tosa, Satsuma, and Choshu (Sakata and Hall 1956, p.43). The kobugattai policy permitted feudal domains to enter national politics. At the forefront was Choshu. In 1861, the Nagai Uta, one of the Choshu top officials, proposed to the feudal lord of Choshu a strategy to participate in national politics. ${ }^{10}$ The Choshu lord agreed to this proposal and submitted it to the court and the bakufu. The court and the bakufu accepted the Choshu proposal.

Meanwhile, Shimazu Hisamitsu, a leader of Satsuma, was planning the emergence of this important domain into national politics. On April 16,1862 , Shimazu arrived in Kyoto and began mediating between the court and the bakufu. He submitted to the court a proposal for kobugattai mediation, which was more favorable to the imperial court than that of Choshu. The court which had once supported the Choshu proposal, now turned it down and accepted the Satsuma proposal. Satsuma's ascendance in Kyoto was significant for the development of the shi-shi

\footnotetext{
7 Detailed descriptive studies of the shi-shi political campaigns are provided by Totman (1980), Craig (1959, 1961), and Beasley (1972).

${ }^{8}$ Kyoto was the capital of Japan. The shi-shi political campaigns in Kyoto were attempts to exert national influence through the growing importance of the imperial court which was located there.

${ }^{9}$ Konishi points out that the meaning of kobugattai was taken in various ways. The bakufu adopted this policy to restore its authority through the attachment to the emperor. For the emperor, the coalition with the bakufu was the first step to stabilize the nation and to fight against foreigners. For some feudal lords, this policy meant an opportunity to participate in national politics (Konishi 1966, p.216). Thus, the wide support for this policy was based in constellation of perceived interests rather than consensus on the concepticy was based

${ }^{10}$ Nagai's proposal "was ostensibly a compromisensus on the concept of the policy. the bakufu" (Huber 1981, country temporaily and country temporarily and acquire industrial and military power through trade. Then it would return to its seclusion policy under the leadership of the emperor with the bakufu cooperation (Shibahara 1975, p.176).
}

Violence in the Shi-Sbi Movement political campaigns, because it enabled shi-shi of Choshu to tum the policy of this domain toward the anti-bakufu ideology of sonno-join ${ }^{11}$ (Huber 1981, p.108; Craig 1961, p.174).

Before Choshu was superseded in national politics by Satsuma, the $s b i$-shi in Choshu had condemned Nagai's kobugattai proposal as no better than the bakufu policy to open the country to foreigners. These shi-shi opposed even the temporary discarding of the seclusion policy (Shibahara 1975, p.178). Choshu's loss to Satsuma in the competition for influence in Kyoto was the opportunity which permitted a shi-shi political campaign to turn the government of Choshu toward a more radical challenge to the bakufu. On July 6,1862, the Choshu government adopted sonno-joi as the official domain policy.

Once the sonno-joi position was adopted by the Choshu government, shi-shi from Choshu began to exert influence on the imperial court in the name of Choshu. Shi-shi contacted the court nobles who favored the sonno-joi position ${ }^{12}$ and supported them. Also, shi-shi strengthened their influence on the decisions of the court by frequent use of violence against the bakufu officials and the court nobles who had the conflicting political plans ${ }^{13}$.

Tilly argues that "contention of power consists of the application of resources to influence other groups, and power itself consists of a group's making its interests prevail over others with which they are in conflict. Contention for political power involves applying resources to a particular kind of organization: a government" (Tilly 1978, p.125). The course of the shi-shi political campaign in Kyoto can be seen as a series of resource acquisitions and applications. First, the shi-shi utilized their personal relationships with Choshu officials to turn the domain policy toward sonno-joi. Then, the domain support for sonno-joi was utilized as a resource to exert influence on the imperial court.

This political campaign proved effective. The imperial court which had earlier dismissed Choshu's mediation in favor of that of Satsuma now dropped Satsuma and aligned with Choshu. On August 27, 1862, an imperial decree for the expulsion of foreigners was issued. On October

1 Sonno-joi literally means "revere the emperor and expel the barbarians." As a political idea, it was the antithesis of kobugattai position. Although both aimed at national reconstruction and expulsion of foreigners, they differed over whether temporary entry of foreigners into Japan was an acceptable method to achieve the goal.

12 In this paper, the term "sonno-joi court nobles" means the court nobles who favored the sonno-joi position and cooperated the sbi-sbi campaign.

${ }^{13}$ I will call these court nobles "kobugattai court nobles", since they supported the kobugattai policy. The later-stage pattern of shi-shi violence is discussed in the next section of this paper. 
27, an imperial mission handed the imperial decree of joi to the bakufu. On December 5, the bakufu accepted the joi order. In the meantime, the sonno-joi court nobles in Kyoto and shi-shi samurai petitioned the court for the creation of imperial troops, with the excuse of protecting the court from the barbarians (Shibahara 1975, p.193). In the early months of 1863, the shi-shi of Choshu tightened their hold over the imperial court by influencing the emperor through sonno-joi court nobles to create new positions in the court and to appoint court nobles favorable to the sonnojoi cause.

At the same time, shi-shi had been demanding in the name of the imperial court that the bakufu set a definite date to carry out the joi order. On April 20, the bakufu reluctantly informed the court that the expulsion of the barbarians would begin on May 10, 1863 (Huber 1981, p.119). These events suggest that in 1862 and 1863, for the first time in Tokugawa period (1603-1867), national politics in Kyoto were no longer controlled by the bakufu. Shibahara claims that the political situation was as if there were "two national governments within one nation" (1975, p.202). The imperial court during these years was a resource gained and used by shi-sbi to legitimize their actions and to compete with the bakufu policy.

The shi-shi activists directed sustained political campaigns at several levels of the existing polity, most significantly toward the governments of several feudal domains, the imperial court, and the bakufu itself. However, the concrete process of the shi-shi movement shows concurrent sporadic violent actions were also a significant part of the movement in 1862 and 1863. In the following section I will document violent actions in this later phase of the shi-shi movement.

\section{Later Shi-Shi Violence}

Ando Nobumasa's kobugattai policy, begun in 1861, was initially well accepted by the imperial court and even the lords of tozama domains with little loyalty to the bakufu. Shi-shi activists opposed it, however. While most powerful opponents of the bakufu still supported the kobugattai policy, shi-shi criticized it, characterizing the marriage between the shogun and the emperor' sister as sending her as a hostage to the bakufu (Shibahara 1975, p.140). On January 15, 1862, four shi-shi from Mito attacked Ando, who managed to escape with his life but lost his political power ${ }^{14}$. The shi-shi political campaigns (described above) followed.

14 The Japanese feudal system was led by individuals of the samurai (warrior) class. The leader of the bakufu was supposed to be the leader of warriors, whose code of behavior (at least ideally) was chivalrous. Thus, escaping from the attack by the lower class samurai was disgraceful enough to deprive Ando of his power in the system. 178
A series of "tenchu" (heaven's revenge) assassinations coincided with the shi-shi political campaigns. According to Huber, "tenchu was unmistakably political in its timing, its objectives, its publicity activities and its effects. One of the peculiarities ... lay in its uncanny timing.... The abrupt oscillations in the assassination rate can easily be explained by reference to concurrent political events" (1982, pp.109-110). During 1861 and the first half of 1862 , only four incidents of political terrorism had been recorded. Then, in the second half of 1862 and 1863, forty-six terroristic incidents were recorded (Hirao 1930). Similar to the violent actions during the early phase of the movement, there is no evidence that these assassinations were under the coordination and control of any particular social movement organization. Also, there is no indication that individual incidents of violence in the later phase were more organized or centrally coordinated than the incidents in the early phase of the movement.

The first tenchu assassination was of Shimada Sakon on July 20, 1862 (Konishi 1966, p.257; Shibahara 1975, p.186; Huber 1982, p.112). Shimada, a retainer of a court noble, had spied on opponents of the international treaty which permitted foreigners to enter Japan to trade. Shimada revealed opponents' identities to the bakufu who killed many of them during the Ansei purge. Tanaka Shinbei, a shi-shi from Satsuma, killed Shimada, whose head was publicly displayed. A script was left with his head, saying "he is a great traitor unfit for heaven or earth" (Huber 1982, p.113). In August, 1862, Okada Izo, a shi-shi from Tosa, killed and publicly displayed the head of a bakufu officer who also had played a role in the Ansei purge.

"The largest single stroke of tencbu assassination" (Huber 1982, p.112) occurred on September 23, 1862. Four bakufu officials in Kyoto, on their way to Edo, were killed by a group of shi-shi, which included Tanaka (from Satsuma), Okada (from Tosa), and Kusaka (from Choshu). The assassinated officials were sergeants of police under the bakufu's city commissioner in Kyoto, and had been very active during the Ansei purge (Shibahara 1975, p.188; Huber 1982, p.112). In early 1863, violent actions continued against court nobles and bakufu officials (Morikawa 1967; Hirao 1930).

Edwards argues that "terrorism is under the control of small number of individuals" ([1927] 1970, p.103). There is not sufficient evidence, however, to support an argument that the series of tencbu assassinations in the shi-shi movement can be explained by the coordination of a small number of particular individuals. Oliver notes that "social movements are ... made up of lots of small collective units, each [possibly] acting 
autonomously in accord with their own internal logic" (Oliver 1989, p.4). Actions and events within a movement influence each other, but they are "outside the control or direction of any person or organization" (Oliver 1989 , p.4). Seeing the shi-shi movement in 1862-63 as interdependent actions without centralized control seems consistent with Huber's (1981) careful conclusion that "the sympathetic nobles in the court provided the $s h i$-shi movement with imperial support for radical activism. The court, Choshu, and tenchu assassinations worked in concert" (Huber 1981, p.118). The imperial court's acceptance of Choshu's sonno-joi proposal and the personal relationships between the shi-shi activists and the officials in Choshu affected the occurrence and timing of shi-shi direct action. This does not mean that shi-shi violence was centrally controlled or coordinated.

The vital political role of mediation between the court and the bakufu was given to Choshu in the summer of 1862 . It was precisely during this ascendancy of shi-sbi-led Choshu in national politics that political assassinations -- carried out by shi-shi who supported the same sonno-joi objectives advocated by Choshu -- occurred most frequently in Kyoto. Huber concludes that the shi-shi who engaged in the assassinations were almost certainly responding to the significantly improved political environment that the Choshu mediation represented (Huber 1982, p.110). Huber's argument of reciprocity between Choshu's political ascendance and the tenchu assassinations is also supported by the fact that assassinations ceased as soon as Choshu sonno-joi faction was expelled from Kyoto in the summer of 1863. These significant patterns of violence in the shi-shi movement seem to directly contradict certain interpretations of "later stage" violence.

\section{Discussion}

This paper has traced the process of the shi-shi movement, and raised the issue of the characterization of social movement stages in terms of violence. The literature shows contrasting viewpoints on violence and movement stages. Some scholars (Blumer 1939; Hopper 1950; Turner and Killian 1987) characterize violence as a sporadic type of action found in an early movement stage. Others (Tarrow 1993; McAdam 1983; Miller 1983; Feagin and Hahn 1973) say that violence is characteristic in a later movement stage which occurs after the loss of outside support and resources.

The examination of the shi-shi movement reveals several contrasts with these arguments. First, the characterization of movement stages in terms of the presence or the absence of violent actions does not capture the empirical patterns in the shi-shi movement. As this paper has shown,
Violence in the Shi-Shi Movement violent actions continuously occurred in the shi-shi movement. As Blumer (1939) argues, the shi-shi movement shows the prevalence of sporadic violent actions in an early movement stage. Also, as Blumer leads us to expect, organized political campaigns developed in the later stage of the movement. Unlike Blumer's model, however, uncoordinated sporadic violent actions continued to occur during the later phase of the shi-shi movement. They were interdependent with, but apparently not coordinated by the organized political campaigns. Also, unlike Tarrow (1994), McAdam (1983) and Miller (1983) suggest, violent actions are not confined to a later period of the social movement.

Second, unlike the argument that violent actions occur when political opportunities for movements contract, violent actions occurred continuously (and increased) in the shi-shi movement when political opportunity had expanded in favor of the shi-shi causes. The coincidence of tenchu assassinations and the success of shi-shi political campaigns shows that violent actions may increase even when political opportunities allow more conventional actions. In this case, at least, violence is not an effect of narrowing support or the loss of resources.

These empirical differences of the shi-shi movement from the theoretical models of violence and movement stages direct students of social movements to several issues. First, the description of the shi-shi movement suggests a different basis for stage distinctions. The shi-shi movement can be divided into stages, not in terms of types of actions, but in terms of expansions of its repertoire of actions. Blumer's notion of a movement's stage is based on types of action, "sporadic, dispersed" actions in the early phase and "organized, solidified and persistent" actions in the later period (1939, p.259). The shi-shi movement shows that the early sporadic violent actions were supplemented by rather than replaced by organized, coordinated action in a later stage. The repertoire of actions actually used in the movement diversified as it developed ${ }^{15}$. Thus, instead of characterizing each phase of the shi-shi movement in terms of $a$ type of prevalent action, it is more correct to say that the transition to a later stage occurred when the repertoire of actions actually used by movement participants expanded.

15 Tarrow (1989, pp.49-56, 1993, pp.284-287) discusses the cycle of protest and the expansion of the repertoire of contention. Tarrow argues that "new forms of collective action develop within the experimental context of cycles of protest. The most successful becomes part of the future repertoire of collective action" (1993, p.286). My argument of repertoire of actions as the basis of stage differs from Tarrow's discussion in the sense that Tarrow views the repertoire as "not only what people do, [but] what they know how to do" (1993, p.283). Movement stages are distinguished in terms of actions taken, not actions that could be taken. 
Second, during the shi-shi movement, violent actions coincided with organized political campaigns. That is, violent actions occurred most frequently when the structure of political opportunity was most favorable for movement participants to use non-violent actions. This contrasts with the concrete patterns of violence attributed to the American civil rights movement and student movements in the United States. In these movements (as Tarrow, 1994, observes), violent actions occurred when the movements lost outside support and the political opportunities became unfavorable. Further analysis of the social mechanisms relating political opportunity with movement violence is necessary.

Third, the usefulness of the notion of a generalized social movement career needs to be reassessed. A characterization of the phases of any social movement can provide a model to compare and contrast with other cases. The stages characterized from the analysis of the shi-shi movement, however, are not claimed to be a generalizable model of social-movement careers. Rather, it is a "hypothesis forming model" (Kalberg 1994) which may be used to focus empirical examinations of other cases.

This paper has discussed contrasting characterizations of the place of violence in stages of social movements, as it examined the shi-shi movement in 19th century Japan. It is a single case study. It by no means constitutes a fully-developed criticism of the characterizations of movement stages in terms of violence. The results of this empirical study of the shi-shi movement, however, vary from Blumer's or Tarrow's tendencies to see violence as characteristic of a particular stage of social movements. At least, this analysis of the shi-shi movement, points out a significant variation from models that characterize movement stages in terms of violent actions.

\section{References}

Beasley, William G. 1972. The Meiji Restoration. Stanford, CA: Stanford University Press.

1990. The Rise of Modern Japan. London: Wedenfeld \& Nicolson.

Blumer, Herbert. 1939. "Collective Behavior." Pp. 221-280 in An Outline of the Principles of Sociology, edited by Robert E. Park. New York: Barnes \& Noble Inc.

1978. "Social Unrest and Collective Protest." Studies in Symbolic Interaction 1:1-54.
Violence in the Shi-Shi Movement

Craig, Albert M. 1959. "The Restoration Movement in Choshu." Journal of Asian Studies 18:187-197.

1961. Chosbu in the Meiji Restoration. Cambridge, MA: Harvard University Press.

Davies, James C. 1962. "Toward a Theory of Revolution." American Sociological Review 27:5-19.

Della Porta, Donatella. 1995. Social Movements, Political Violence, and the State. Cambridge, England: Cambridge University Press.

Duus, Peter. 1976. The Rise of Modern Japan. Boston: Houghton Mifflin.

Edwards, Lyford. 1970[1927]. The Natural History of Revolution. Chicago: University of Chicago Press.

Evans, Emest. 1983. "The Use of Terrorism by American Social Movements." Pp. 252-261 in Social Movements of the Sixties and Seventies, edited by Jo Freeman. New York: Longman.

Feagin, Joe R, and Harlan Hahn. 1973. Ghetto Revolt. New York: MacMillan Publishing Co.

Gurr, Ted Robert. 1970. Why Men Rebel Princeton, NJ: Princeton University Press.

Harootunian, Harry D. 1970. Toward Restoration: The Growth of Political Consciousness in Tokugawa Japan. Berkeley: University of California Press.

Hesselink, Reinier H. 1994. "The Assassination of Henry Heusken." Monumenta Nipponica 49:331-351.

Hirao, Michio. 1930. Ishin Ansatsu Hiroku (Records of Assassination in the Restoration Era). Tokyo: Hakuyusha.

Hopper, Rex. 1950. "Revolutionary Process: A Frame of Reference for the Study of Revolutionary Movements." Social Forces 28:270279.

Huber, Thomas M. 1981. The Revolutionary Origins of Modern Japan. Stanford, CA: Stanford University Press. 
1982. "Men of High Purpose and the Politics of Direct Action, 1862-1864." in Conflict in Modern Japanese History, edited by Tetsuo Najita and J. Victor Koschmann. Princeton, NJ: Princeton University Press.

Jansen, Marius. 1961. Sakamoto Ryoma and the Meiji Restoration. Princeton, NJ: Princeton University Press.

Kalberg, Stephen. 1994. Max Weber's Comparative-Historical Sociology. Chicago: University of Chicago Press.

Konishi, Shiro. 1966. Kaikoku to Joi (The Opening of Japan and Expulsion Movement). Tokyo: Chuo-Koron.

McAdam, Doug. 1982. Political Process and the Development of Black Insurgency, 1930-1970. Chicago: University of Chicago Press.

1983. "The Decline of the Civil Rights Movement." Pp. 298319 in Social Movements of the Sixties and Seventies, edited by Jo Freeman. New York: Longman.

1986. "Recruitment to High-Risk Activism: The Case of Freedom Summer." American Journal of Sociology 92:64-90.

McAdam, Doug, and Kelly. Moore. 1989. "The Politics of Black Insurgency, 1930-1975." Pp. 255-285 in Violence in America: Protest, Rebellion, Reform, edited by Ted Robert Gurr. Newbury Park, CA: Sage Publications.

McCarthy, John, and Mayer Zald. 1977. "Resource Mobilization and Social Movements: A Partial Theory." American Journal of Sociology 82:1212-1241.

Miller, Fredrick D. 1983. "The End of SDS and the Emergence of Weatherman: Demise Through Success" Pp. 279-297 in Social Movements of the Sixties and Seventies, edited by Jo Freeman. New York: Longman.

Morikawa, Tetsuro. 1967. Bakumatsu Ansatsushi (History of Assassination during Bakumatsu Period). Tokyo: Sanichi Shobo.

Oberschall, Anthony. 1973. Social Conflict and Social Movements. Englewood Cliffs, NJ: Prentice-Hall Inc.
Violence in the Shi-Sbi Movement

1993. Social Movements: Ideologies, Interests, and Identities. New Brunswick, NJ: Transaction Publishers.

Oliver, Pamela E. 1989. "Bringing the Crowd Back In." Research in Social Movements, Conflicts and Change 11:1-30.

Pyle, Kenneth. 1978. The Making of Modern Japan. Lexington, MA: D.C. Heath and Company.

Rule, James B. 1988. Theories of Civil Violence. Berkeley: University of California press.

Sakata, Yoshio, and John W. Hall. 1956. "The Motivation of Political Leadership in the Meiji Restoration." Journal of Asian Studies 16:31-50.

Shibahara, Takuji. 1975. Kaikoku (The Opening of Japan). Tokyo:Shogakukan.

Snyder, David. 1979. "Collective Violence Processes: Implications for Disaggregated Theory and Research." Research in Social Movements, Conflict, and Change 2:35-61.

Snyder, David, and Charles Tilly. 1972. "Hardship and Collective Violence in France, 1830 to 1960." American Sociological Review 37:520-532.

Tarrow, Sidney. 1989. Struggle, Politics, and Reform: Collective Action, Social Movements, and Cycles of Protest. Ithaca, NY: Comell University, Western Societies Paper no.21.

- 1993. "Cycles of Collective Action: Between Moments of Madness and the Repertoire of Contention." Social Science History 17:281-307.

- 1994. Power In Movement. Cambridge, England: Cambridge University Press.

Tilly, Charles. 1978. From Mobilization to Revolution. Reading, MA: Addison-Wesley Publishing Company.

. 1993. "Contentious Repertoires in Great Britain, 1758-1834." Social Science History 17:253-280. 
Tilly, Charles, Louise Tilly, and Richard Tilly. 1975. The Rebellious Century: 1830-1930. Cambridge, MA: Harvard University Press.

Totman, Conrad. 1975. "Tokugawa Yoshinobu and Kobugattai: A Study of Political Inadequacy." Monumenta Nipponica 30:393-403.

1980. The Collapse of the Tokugawa Bakufu, 1862-1868. Honolulu: University Press of Hawaii.

Turner, Ralph H., and Louis M. Killian. 1987. Collective Behavior (3rd ed.). Englewood Cliffs, NJ: Prentice-Hall.

\section{BOOKS: REVIEWS AND ESSAYS}

\section{THE PEOPLE, THE ENEMY, AND THE VISION: A REVIEW ESSAY}

Millennium Rage: Survivalists, White Supremacists, and the Doomsday Prophecy. By Philip Lamy. 1996. New York: Plenum Press. Hardback. 295 pages.

Fascism: Past, Present, and Future. By Walter Laquer. 1996. New York: Oxford University Press. Hardback. 263 pages.

All-American Monster. The Unautborized Biography of Timothy McVeigh. By Brandon M. Stickney. 1996. Amherst, New York: Prometheus Books. Hardback. 336 pages.

\section{GEORGE LUNDSKOW \\ University of Kansas}

MARS/Social Thought \& Research, 1997, Vol. 20, No. 1-2

Increasingly, scholars are looking at right-wing extremist and fascist movements today in the post cold war era. Instead of broader freedom, opportunity, and peace, the collapse of the Soviet Union has brought uncertainty, fear, and aggression. Some of the new movements chillingly recall Nazism and fascism from mid-century, while other incorporate new beliefs and agendas. A full understanding requires an historical perspective, to understand the development of the beliefs and changes over time as social conditions change, and also a look at what type of person joins an extremist movement, and why. All three books rely primarily on historical narrative. Although the timeframe varies, all seek to reconstruct the past as a means to understand the present. All three more or less succeed with this effort, but all three similarly lack a theory to explain possible causal relationships. Basically, they narrate historical events in their proper context, but they mostly do not discuss the findings beyond their immediate meaning. All three tend to take what people or groups say about themselves at face value, and do not critically analyze it further. Lamy and Laquer in particular discuss the wide array of right-wing extremist groups today, an array sufficiently diverse that the 